\title{
THE SIGNIFICANCE AND MODALITIES OF INTERNET ABUSE AS THE PRIMARY GLOBAL COMMUNICATION COMPUTER NETWORKS IN CYBERSPACE
}

\begin{abstract}
Along with the rapid development of computers, computer networks have also been developed. Computer crimes are carried out in a specific environment - cyberspace, whose important characteristic is transnational scope, which goes beyond the control of the territorial nation-states. There is no doubt that computer networks can be subject of various abuses. They appear in a triple role: as a target or object of the attack, as a means or a tool, or as a framework of the offense. This kind of crime rapidly changes forms and forms of manifestation, the border between the states and the other injured. The biggest problem in this area is the misuse of the Internet, as the main global computer network communication, which has fundamentally revolutionized many areas of human life and work. The subject of this paperwork is analyzing the most important modalities of Internet abuse, as well as the scope and importance of using the Internet in a modern society. A separate section is dedicated to case studies of judicial authorities in Republic of Serbia.
\end{abstract}

Key words: cyber space, computer networks, Internet, case study.

\section{Introduction}

Opposed from traditional forms of crime, cyber crime is characterized by considerably expanded scope of criminal activities that do not require the presence of the perpetrator at the scene of the crime. Users of computer technology can move in the virtual world of IT, without control, regardless of the time category or where the offender is located.

Since computer crimes are carried out in a specific environment, called cyberspace, it implies a lot of new and interesting implications. Bearing in mind this important feature of cyber crime, "the fact that is performed in the informa-

Jelena Matijašević Obradović, PhD, Assistant Professor at The Faculty of Law for Commerce and Judiciary, The Universitey of Bussines Academy, Novi Sad, e-mail: jela_sup@yahoo.com 
tion environment, gives some specifics which are reflected on the fact that crime in the information environment compared to the classic situation is running easier, faster, more varied, extensive and more anonymous, which is the most important from the criminals point of view. ${ }^{1}$

Cyber space offers endless possibilities: different ways of communication with other persons and expressing their own thoughts and feelings, informative, and free pieces of information regarded to any topic, various forms of entertainment, business opportunities and more. An important feature of cyberspace is a global and transnational scope, that goes beyond the control of the territorial nation-states.

The term cyberspace („,cyberspace”) was first used by William Gibson in a trilogy of science fiction "Neoromancer”, which was published in the 1984th year. ${ }^{3}$ Inspired by first reviewing the term cyberspace, many authors had chosen to determine more precisely the meaning and characteristics of this new phenomenon, in their papers. Cyber space as a distinctive and individual dimension, during the time has crystallized its present meaning. Michael Benedict considers cyber space as a "new universe, a parallel universe created and maintained by using” computer world “ and lines of communication." Kevin Hughes gives us different perspective and defines cyberspace as "mutually connected environment via computer which are presented to all previously created media." According to current views, cyberspace is seen as a new social action dimension and social topology, which was developed from computer networks, particularly the Internet. Cyberspace is a socio-cultural layer, required upgrade of the technical infrastructure of the Internet. As virtual reality, it enables entirely new forms of social action. It is a prerequisite and a result of modern social knowledge's.

Accordingly, cyber space is an artificial creation that requires high technical equipment, a good information infrastructure that is anyone's and everyone

$1 \quad$ Petrovic, S.: „About information revolution in the context of information technology abuse“, 6; http://www.itvestak.org.rs/ziteh_04/radovi/ziteh-20.pdf (20.09.2010.)

2 Gibson, W.: Neuromancer, An Ace Book, The Ace Publishing Group, New York, 1984, Electronic edition: August 2003

3 On page. 51, William Gibson provides this description of Cyberspace: "Cyberspace. A consensual hallucination experienced daily by billions of legitimate operators, in every nation, by children being taught mathematical concepts...A graphical representation of data abstracted from the banks of every computer in the human system. Unthinkable complexity. Lines of light ranged in the non-space of the mind, clusters and constellations of data. Like city lights, receding..."

4 Benedikt, M.: Ed. Cyberspace First Steps. Cambridge, MA, MIT Press, 1991, quoted by: Schneider, V and Hyner, D.: The Global Governance of Cybercrime: Issue Space and the Transnational Policy Network, University of Konstanz, 2003, 4; http://www. essex.ac.uk/ecpr/events/jointsessions/paperarchive/edinburgh/ws11/SchneiderHyner.pdf (28.08.2010.)

$5 \quad$ Hughes, K.: From Webspace To Cyberspace, 1995, quoted by: Schneider, V and Hyner, D., 4. 
else's property, which coexist in parallel virtual and real, and with whom the communication is collective. In such environment, it is extremely difficult to talk about crime and national scale social danger, at least not in the conventional sense of the word. Therefore this crime is classified as the most prominent form of transnational crime against which struggle can not be conventional. Social and economic context of the crime is not identical with classical transnational crime in cyber space, because different rules are applies - which shows global study on Organized Crime (Global studies on organized crime) of the Center for the Prevention of Crime and the International Institute for the Research of the United Nations interregional crime. ${ }^{6}$

Bearing in mind the previous introductory notes aimed at clarifying spatial component as a kind of framework for various abuses of information technology, this paper will be focused on significance and modalities of Internet abuse, as the primary global communication computer networks in cyberspace.

\section{The most important modalities of Internet abuse}

There is no doubt that a computer network can be a subject of various abuses, object of action of more crimes and can be found in several different roles. Furthermore, there are different categories of perpetrators of cyber crime, since there are many different criminal acts which they make and bearing in mind motives that drive them to carry out these activities. ${ }^{\text {? }}$

Crime related to computer networks is a form of criminal behavior in which the specificity of the environment is the reason why computer networks appear in a triple role: as the goal or object of the attack, as a means or a tool, or as a framework of the offense.

If we observe computer network as a target or object of attack, we recognize services which have been attacked, functions and facilities that are located on the network. Services and data's are being steeled, parts or entire networks and computer systems are being damaged or destroyed and computer systems and their functions are being disrupted.

In 1998. the first mass attack on the Internet was occurred, when in the network is loaded worm that destroyed data on computers and spreads across

$6 \quad$ United Nations office at Vienna, Global studies on organized crime, 1999., http://www. oun.org cited according to: Drakulic, M. i Drakulic, R: „Cyber kriminal“, http://www.bos. rs/cepit/idrustvo/sk/cyberkriminal.pdf (03.09.2010.)

7 Matijasevic, J.; Spalevic, Z.: „Specific characteristics of computer criminal offenses with regard to the law regulations", XLV International Scientific Conference on Information, Communication and Energy Systems and Technologies - ICEST 2010 CONFERENCE, 23.-26. June 2010., Faculty of Technical Sciences, University „St. Clement Ohridski“, Bitola, Ohrid, Macedonia, 2010, Proceedings, (http://www.icestconf.org/index.php?option=com _ content\&view=frontpage\&Itemid=98, (05.02.2011.) 
the network independently („computer worm”), who made a lot of damage and virtually destroyed nearly a third of U.S. internet content. For subsequent years, there was almost no website important government institutions in the United States, multinational corporations, international organizations which was not "hacked" or whose content was not deleted, replaced or removed with other content on the Internet for some time, by making unauthorized access to a computer-server which kept track of information on these sites. In 2003. was released so far most destructive worm, called. "Sapphire worm”, which in within ten minutes had infected $90 \%$ computer systems on the planet who did not have (adequate) protection. ${ }^{8}$

If we observe network as a means or a tool, we find that a large number of modern criminals use more and more computer networks as a tool to carry out their intentions, due to environmental possibilities.

"Cyber stalking” is an example of using computers and the Internet as a tool of making traditional crimes easier. This term, generally refers to the use of the Internet, e-mail or other means of electronic communication for "hunt” on the other person, where "stalking” in the traditional sense, means the participation in the repeated harassment or threatening behavior such as face tracking, disturbance by phone, or sending threatening messages or objects, which causes the victim reasonable fear for life or bodily integrity. ${ }^{9}$ Disturbance primarily takes places through the endless sending electronic messages to a person who does not want or have no reason to communicate with the sender. Harassment can take the form of threats, sexual associations, pejorative labeling using hate speech, Anti-Semitism, nationalism, etc.. Specific form of harming the reputation of an individual using a global computer network capacity, is sending emails harmful content to a site, where the sender is signed in as someone else, who wants to offend or undermine his reputation by sending messages.

According to research conducted in Privacy Rights Clearinghouse (PRC), a nonprofit consumer organization in San Diego, California ${ }^{10}$, whose main aim is protection of people's privacy, there are proven tactics that include cyber stalking. These are: sending manipulative, threatening, harassing or obscene e-mail messages from a range of e-mail, the invasion victims online accounts and

8 How dangerous cyber crime, it can be seen from the attack, which took place in February 2007. year, when the "hackers" attacked simultaneously, in order to complete incapacitation, six of the thirteen so-called root servers on the Internet. If they succeeded in their intention, it would be completely stopped functioning. Fortunately, there are only two servers suffered significant consequences. Source: Mannes, A.: „Threats to Internet“, Computer Crime Research Center, 2007; http://www.crime-research.org/articles/threat-tiinternet (06.02.2011.)

9 The Attorney General Report, Cyberstalking: A New Challenge for Law Enforcement and Industry, http://www. usdoj.gov/criminal/cybercrime (25.08.2010.)

10 More about in: Privacy Rights Clearinghouse (PRC), a nonprofit consumer organization, San Diego, California, http://www.privacyrights.org/about_us.htm (01.02.2011.) 
change the settings and passwords that the victim was set, creating false accounts for online social networking, using of the victim's personal information or establishing contact with the victim by using false information, sending messages to online forums, discussion groups, with victims personal information such as home address, phone number or social security number. Messages can be rude or controversial, and as result victim receives numerous messages, calls or visits from people who read the messages on the network, reporting for a number of mailing lists and online services, using the victim's name and e-mail. ${ }^{11}$

Research constructed in this area within the education system, „Ruder Boskovic" from Belgrade came to a very alarming data. In order to explore the possibility of abuse chat rooms ${ }^{12}$ compared to the children's population, the model of „virtual girl” was used. The results show that the "virtual girl” spent a total of 80 hours a month in one Internet chat rooms. She has managed to achieve over 412 contact (not on his own initiative), with 398 males, without any highlighting their own personality and without showing the pictures. Different forms of sexual harassment occurred 162 times, 24 times she was exposed to sexual fantasies and 6 times she was offered money for sexual favors. ${ }^{13}$

We will mention one more way of using computer networks. Sending e-mail has become the most common form of communication in last years According to current research in this area, in 2009. average of sent e-mail messages per day was 247 billion, while in 2010. the number was 294 per day. Data of 294 billion messages sent leads us to conclusion that every second more than 2.8 million messages were sent. About $90 \%$ of these messages is spam (spam), or contains malware. ${ }^{14}$ Perpetrators of crimes through spam have countless opportunities to defraud potential customers, damage computer systems in the world within just a few hours and expose the vulnerability of corporations and the state administration by attacking them with computer viruses. Some commercial services include spam botnets for sending these messages that help to avoid anti-spam measures to protect users' computers and servers on the Internet service provider, operating in such a way to block IP addresses that have been posted on the „black list". Today there are a large number of IP addresses from where these messages have been sent and which have been identified as carriers of spam acti-

11 Are you being stalked? - Cybestalking, Privacy Rights Clearinghouse (PRC), San Diego, California, posted-june '94, revised-july '10; http://www.privacyrights.org/fs/fs14-stk. htm\#1 (01.02.2011.)

12 Communication channels and impacts on a specific target group are performed by the passive method through Web Portals with illegal content, while the active method applies to sending e-mail messages, Chat-servise and mobile telephony.

13 The education system "Ruder Boskovic", Abuse of Internet - predators on children, Belgrade, 2003, 7

14 Radicati Group Statistics, http://email.about.com/od/emailtrivia/f/emails_per_day.htm (12.02.2011.) 
vity. ${ }^{15}$ The other side of spam is getting junk mail. Reason for getting junk mail, lays in fact that users leave their valid e-mail address during the registration on websites. Those websites gives users e-mails for free or for fees to different companies, which send a huge number of (real or fake) commercials for various products. There is actually done (illegally) filtering - opposed from the automatic sending to addresses that may not be active or not even there, here are only used existing, active addresses and "provides” the attention of their users. Although this kind of „assignment” of the data is certainly punishable in most countries, according to the regulations of the protection of personal data, it is virtually impossible to determine whether and how some of the sites transferred someone's e-mail address. ${ }^{16}$ In some cases, user himself, allow finding his e-mail addresses on these kinds of lists, by agreeing with this option without reading text carefully, during the registration at a Web portal Web sites.

Most spam messages have marketing aspect. In general, sending this kind o mail is the cheapest way of advertising. However, it is possible to send the spam message, in an attachment, some harmful - the malicious program. If that happens, the case is not in the gray zone of borderline cases, it is a criminal offense.

If we observe the computer network as environmental of a crime, we will recognize that the environment is used to effectively conceal criminal activity.

Computer networks have been devoted as a result of various military and governmental institutions in the United States. These networks were only for internal use, with strong protection against unauthorized intrusion and privacy and without any intention to commercialize. However, several civilian networks were created on such methods, often on different universities, which have experimented with computer networks as a new mode of communication between users. These networks over the past 15 years were replaced by the development of the global computer network - the Internet. ${ }^{17}$

\section{The scope and importance of using the Internet for a modern society}

Particularly pronounced problem in modern society is a misuse of the Internet as the main global computer network communications. If we look at the role, previously explained, in which computer network can take part, we will conclude that Internet is highly suitable primarily as a means of performing various cri-

15 Uljanov, S., Urosevic, V., Ivanovic, Z.: „Cyber crime from the perspective of the international criminal police cooperation ", Proceedings of the international scientific conference International and national cooperation and coordination in the fight against crime, International Association of Criminologists, Banja Luka, Vol. 3, 1/2010, 530-541, 534

16 Prlja, D., Reljanovic, M.: „Cybercrime - comparative Experiences“, Foreign legal life, Institute of Comparative Law, Belgrade, 3/2009, 171.

17 Komlen-Nikolic, L. et.al.: Combating cyber crime, the Association of Public Prosecutors and Deputy Public Prosecutors of Serbia, Belgrade, 2010, 10 
minal offenses. The problem of the Internet, which is favorable for performance various illicit activities, is an identity. It is difficult to determine someone's internet real identity. An interesting argument for this contention is the text beneath the famous cartoons published 05.07.1993. in the New Yorker-in, which displays a dog who surfs the internet - On the internet nobody knows you are a dog. ${ }^{18}$ Huge opportunities, which are daily provided to all customers, are constantly subjected to a various abuses. Therefore, it is necessary to provide measures in criminal law, to protect this segment of the computer system.

World's global network has revolutionized many areas of human life and work, by opening unexpected and so far the theory unprecedented possibilities of human communication and exchange of information in different fields of human creativity. That offers a new dimension of scientific research, commercial activities, state planning, warfare, threats and creating security. New opportunities for planning, preparation and execution of various types of crime, propagation of dangerous ideas, ideology and information have be created as well as opportunities for action and cooperation of the security services, strengthening the safety culture of citizens and establishing a partnership of all stakeholders of the security system at different levels. ${ }^{19}$

Since the second half of the nineties until now, researchers are examining the effect of Internet on social relationships, habits and personality of the user. The Internet is presented as significant for streingtheing the existing stable social relationships, streingtheing social activities, for forming identity and personality. On the other hand, Internet is blamed for the development of overwhelmingly, weak relationships with acquaintances (instead of the previously nurtured stable, strong relationships with relatives, friends), social isolation, loneliness, depression, and other offensive behavior. Early skepticism of the positive impact on social relations of the Internet was influenced by two University Studies: Carnegie Mellon ${ }^{20}$ and Stanford ${ }^{21}$. The public was informed that Internet not only does not encourage sociability, but has negative effects, where the same phenomenon called Internet paradox ${ }^{22}$. Time which people spend reading newspapers, watching TV, shopping, driving under the influence of the Internet decreases

18 Reed, C.: Internet Law - Text and Materials, London 2000, quote according to: Babovic, M.: „The hacker subculture and Computer Crime“, Legal Life, The Association of Lawyers of Serbia, Belgrade, Year LIII, 9/2004, Book 485, 1-1356, 744

19 Kesetovic, Z.: „Internet as a tool of terrorists“, Journal of Safety, The Center for Security Studies, Belgrade, Year II, 4/2008, 37

20 Kraut, R. et. al.: „Internet paradox: A Social Technology That Reduces Social Involvement and Psychological Well-Being?" American Psychologist, 53, 9/1998, 1017-1031

${ }^{21}$ Nie, N., Erbring, L.: "Internet and Mass Media: A Preliminary report", IT\&SOCIETY, 1, 2/2002, 134-141

22 Kraut, R. et. al., Ibid.

Vol. 11, No 1, 2014: 279-298 
and the number of working hours at home and at work increases. ${ }^{23}$ The results of the study of those respected institutions were later constantly disputed, including the authors of the study, and in their later works. ${ }^{24}$

A fact which is in favor of the significance of the Internet, as the primary and most important global communication and computer network, is billion users and 100 millions website reached in 2008. Daily average of new users of Internet is 100000 .

Since luxury and abstract experiment, unbeknownst to most people, Internet has become a necessity and a means of information and communication, entertainment and education used daily by a half billion people around the globe (see Figure 1 and 2). Number of users is constantly increasing.

Figure 1: The number of Internet users in the world given by region ${ }^{25}$

\section{Internet Users in the World by Geographic Regions - 2012 Q2}

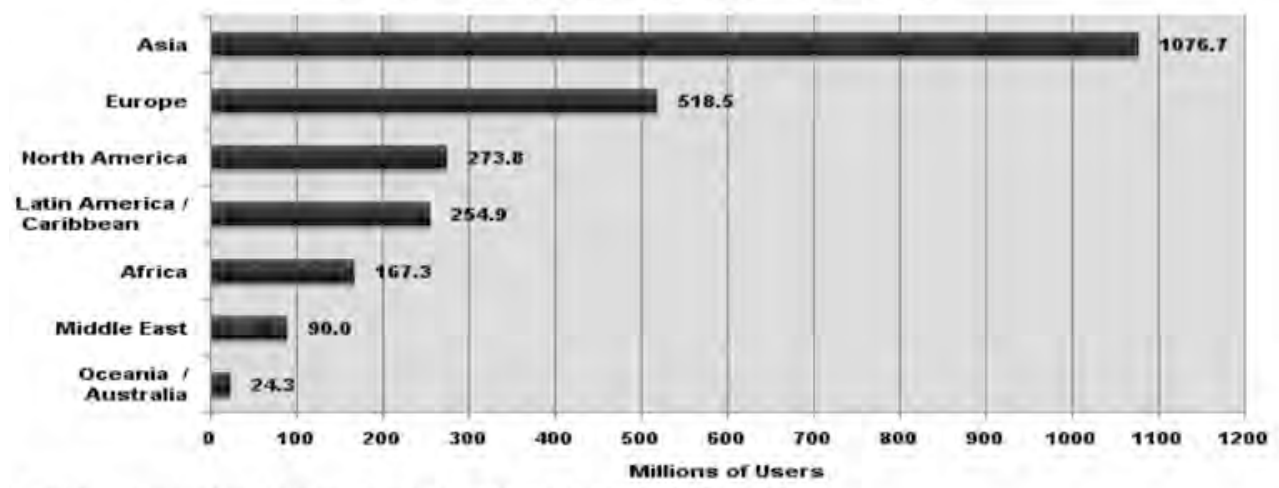

Source internet World Stats - muw internetworidstats com/stats htm $2,405,518,376$ Internet users estimated for June 30, 2012

Copyright @2012, Miniwatts Marketing Group

$23 \quad$ Nie, N. \& Erbring, L., Ibid.

24 Kraut, R. et. al.: "Internet Paradox Revisited. Journal of social science”, 58 , 1/2002, 49-74

25 Internet users ending with the date 30.06.2012. Internet World Stats, Copyright $\odot$ 2012, Miniwatts Marketing Group; http://www.internetworldstats.com/stats.htm (05.04.2013.) 
Figure 2: The number of Internet users in the world by region, expressed in percentage $e^{26}$

\section{Internet Users in the World Distribution by World Regions - 2012 Q2}

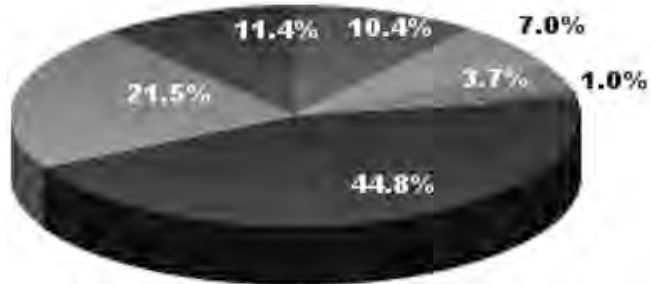

Asia $\mathbf{4 4 . 8} \%$

Europe $21.5 \%$

North America $11.4 \%$

Lat Am / Caribb $10.4 \%$

Africa $7.0 \%$

Middle East $3.7 \%$

Oceania / Australia $1.0 \%$

Source: Internet World Stats - www.internetworldstats.com/stats.htm

Basis: 2,405,518,376 Internet users on June 30, 2012

Copyright @ 2012, Miniwatts Marketing Group

The scope of Internet usage and Facebook, as the most popular Web site that serves as a social network service, it is significante to observe from European level. Internet is also presented in a large percentage in Europe and datas are presented in Table 1 and in 3th third and 4th charts.

Table 1: The usage of Internet in Europe - Internet User Statistics ES Population for 53 European countries and regions

\begin{tabular}{|l|c|c|c|c|c|c|}
\hline \multicolumn{7}{|c|}{ Internet and Facebook Usage in Europe } \\
\hline EUROPE & $\begin{array}{c}\text { Population } \\
\text { (2012 Est. })\end{array}$ & $\begin{array}{c}\text { Pop. \% } \\
\text { of World }\end{array}$ & $\begin{array}{c}\text { Internet Users, } \\
\mathbf{3 0 - J u n e - 1 2}\end{array}$ & $\begin{array}{c}\text { Penetration } \\
\text { (\% } \\
\text { Population) }\end{array}$ & $\begin{array}{c}\text { Internet } \\
\text { \% World }\end{array}$ & $\begin{array}{c}\text { Facebook } \\
\text { 31-Dec-12 }\end{array}$ \\
\hline Europe & $820,918,446$ & $11.7 \%$ & $\mathbf{5 1 8 , 5 1 2 , 1 0 9}$ & $63.2 \%$ & $21.6 \%$ & $250,934,000$ \\
\hline $\begin{array}{l}\text { Rest of } \\
\text { World }\end{array}$ & $6,196,928,476$ & $88.3 \%$ & $\mathbf{1 , 8 8 7 , 0 0 6 , 2 6 7}$ & $30.5 \%$ & $78.4 \%$ & $725,009,960$ \\
\hline $\begin{array}{l}\text { TOTAL } \\
\text { WORLD }\end{array}$ & $7,017,846,922$ & $100.0 \%$ & $\mathbf{2 , 4 0 5 , 5 1 8 , 3 7 6}$ & $34.3 \%$ & $100.0 \%$ & $975,943,960$ \\
\hline
\end{tabular}

Source: Internet usage in Europe - Internet User Statistics \& Population for 53 European countries and regions, http://www.internetworldstats.com/europa2.htm (05.04.2013.)

26 Internet users, ending with the date 30.06.2012. Internet World Stats; Copyright $\odot$ 2012, Miniwatts Marketing Group; http://www.internetworldstats.com/stats.htm (05.04.2013.) 
Figure 3: The percentage of Internet users in Europe $e^{27}$

\section{Internet Users in Europe June 30, 2012}

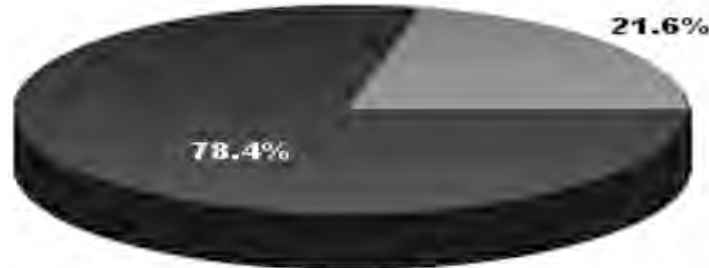

World, $78.4 \%$

Europe, 21.6\%

Source: Internet World Stats - mun.internetworldstats.com

Based on 2,405,518,376 estimated world Internet users for 2012 Q2 Copyright $@ 2012$, Miniwatts Marketing Group

Figure 4: Ten European countries which use the Internet the most ${ }^{28}$

\section{Top 10 Internet Countries in Europe June 30, 2012}

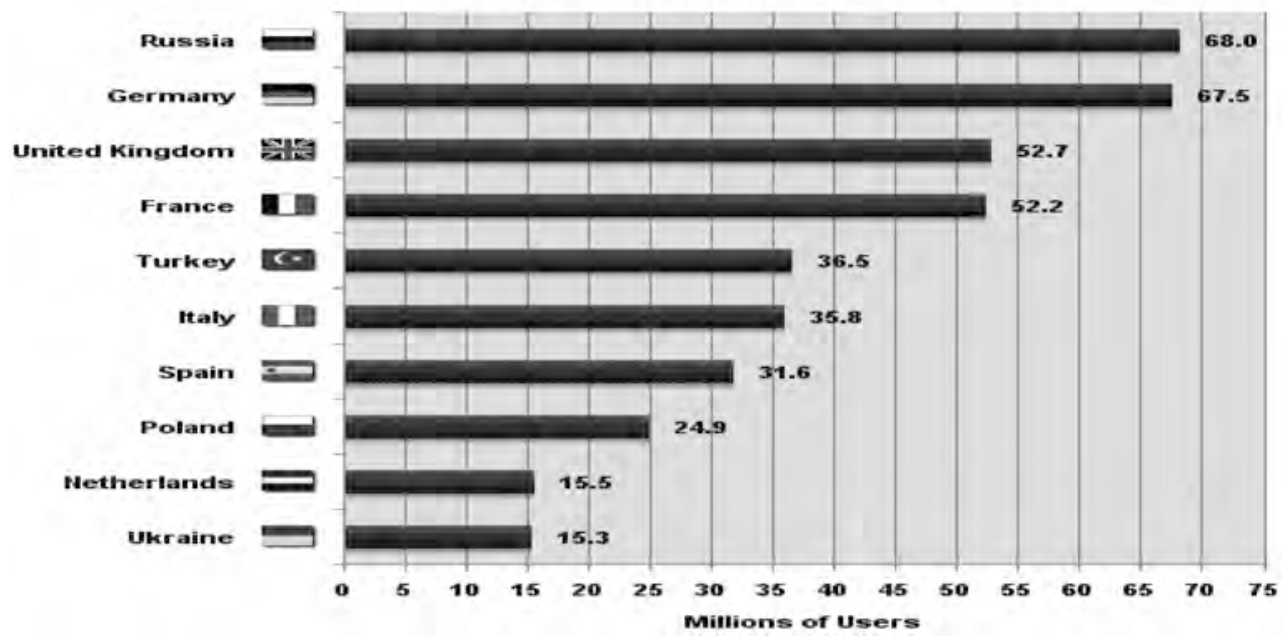

Researches, implemented on the global level, in recent years, included the testing of data related to the area of the European Union. Researches whose results are listed below include an examination of the scope of the Internet usage in the 27 member statesof the European Union. Special overview to the above problem has been made in 9 countries - candidates for entry into the European

${ }_{27}$ The percentage of Internet users in Europe in 2012. year; Internet World Stats; Copyright (c) 2012, Miniwatts Marketing Group; http://www.internetworldstats.com/stats.htm (05.04.2013.)

28 Ten European countries that use the Internet the most; Internet World Stats, Copyright (C) 2012, Miniwatts Marketing Group; http://www.internetworldstats.com/stats.htm (05.04.2013.) 
The significance and modalities of internet abuse as the primary global... 289

Union. The results of these studies are presented below in Table 3 and 4, as well as in Chart 5.

Table 3: The usage of Internet in the European Union

- Internet User Statistics $\mathcal{E}$ Population for the 27 EU member states:

\begin{tabular}{|l|c|c|c|c|c|c|}
\hline \multicolumn{7}{|c|}{ Internet Usage in the European Union } \\
\hline $\begin{array}{l}\text { WORLD } \\
\text { REGION }\end{array}$ & $\begin{array}{c}\text { Population } \\
\text { (2012 Est. })\end{array}$ & $\begin{array}{c}\text { \% Pop. } \\
\text { of World }\end{array}$ & $\begin{array}{c}\text { Internet Users, } \\
\mathbf{3 0 - J u n e - 1 2}\end{array}$ & $\begin{array}{c}\text { Penetration } \\
\text { (\% Population) }\end{array}$ & $\begin{array}{c}\text { Internet } \\
\text { \% Users }\end{array}$ & $\begin{array}{c}\text { Facebook } \\
\text { 31-Dec-12 }\end{array}$ \\
\hline $\begin{array}{l}\text { European } \\
\text { Union }\end{array}$ & $503,824,373$ & $7.2 \%$ & $\mathbf{3 6 8 , 0 2 1 , 9 8 6}$ & $73.0 \%$ & $15.3 \%$ & $192,746,920$ \\
\hline $\begin{array}{l}\text { Rest of } \\
\text { World }\end{array}$ & $6,514,022,549$ & $92.8 \%$ & $\mathbf{2 , 0 3 7 , 4 9 6 , 3 9 0}$ & $31.3 \%$ & $84.7 \%$ & $783,197,040$ \\
\hline $\begin{array}{l}\text { TOTAL } \\
\text { WORLD }\end{array}$ & $7,017,846,922$ & $100.0 \%$ & $\mathbf{2 , 4 0 5 , 5 1 8 , 3 7 6}$ & $34.3 \%$ & $100.0 \%$ & $975,943,960$ \\
\hline
\end{tabular}

Source: The usage of Internet in the European Union - Internet User Statistics \& Population for the $27 \mathrm{EU}$ member states, http://www.internetworldstats.com/europa2.htm (05.04.2013.)

Table 4: The usage of Internet in the EU Candidate Countries:

\begin{tabular}{|l|c|c|c|c|c|}
\hline \multicolumn{7}{|c|}{ Internet Usage in the EU Candidate Countries } \\
\hline $\begin{array}{l}\text { EUROPEAN UNION } \\
\text { CANDIDATES }\end{array}$ & $\begin{array}{c}\text { Population } \\
\text { (2012 Est. })\end{array}$ & $\begin{array}{c}\text { Internet Users, } \\
\mathbf{3 0 - J u n e - 1 2}\end{array}$ & $\begin{array}{c}\text { Penetration } \\
\text { (\% Population) }\end{array}$ & $\begin{array}{c}\text { Users \% } \\
\text { Table }\end{array}$ & $\begin{array}{c}\text { Facebook } \\
\text { 31-Dec-12 }\end{array}$ \\
\hline Albania & $3,002,859$ & $\mathbf{1 , 4 7 1 , 4 0 0}$ & $49.0 \%$ & $3.0 \%$ & $1,097,800$ \\
\hline Bosnia-Herzegovina & $3,879,296$ & $\mathbf{2 , 3 2 7 , 5 7 8}$ & $60.0 \%$ & $4.7 \%$ & $1,345,020$ \\
\hline Croatia & $4,480,043$ & $\mathbf{3 , 1 6 7 , 8 3 8}$ & $70.7 \%$ & $6.4 \%$ & $1,595,760$ \\
\hline Iceland & 313,183 & $\mathbf{3 0 4 , 1 2 9}$ & $97.1 \%$ & $0.6 \%$ & 227,000 \\
\hline Kosovo & $1,836,529$ & $\mathbf{3 7 7 , 0 0 0}$ & $20.5 \%$ & $0.8 \%$ & $\mathrm{n} / \mathrm{a}$ \\
\hline Macedonia & $2,082,370$ & $\mathbf{1 , 1 8 0 , 7 0 4}$ & $56.7 \%$ & $2.4 \%$ & 962,780 \\
\hline Montenegro & 657,394 & $\mathbf{3 2 8 , 3 7 5}$ & $50.0 \%$ & $0.7 \%$ & 306,260 \\
\hline Serbia & $7,276,604$ & $\mathbf{4 , 1 0 7 , 0 0 0}$ & $56.4 \%$ & $8.3 \%$ & $3,377,340$ \\
\hline Turkey & $79,749,461$ & $\mathbf{3 6 , 4 5 5 , 0 0 0}$ & $45.7 \%$ & $73.3 \%$ & $32,131,260$ \\
\hline $\begin{array}{l}\text { Total EU } \\
\text { Candidate States }\end{array}$ & $103,277,739$ & $49,719,024$ & $48.1 \%$ & $100.0 \%$ & $41,043,220$ \\
\hline
\end{tabular}

Source: The usage of Internet in the EU Candidate Countries, http://www.internetworldstats. com/europa2.htm (05.04.2013.) 
Figure 5: Internet users in the European Union ${ }^{29}$

\section{European Union Internet Users June 30, 2012}

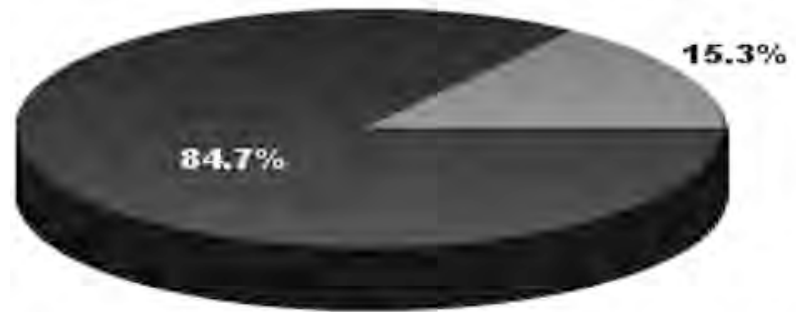

World $84.7 \%$

European Union 15.3\%

Source: Internet World Stats - munvinternetworldstats.com $368,021,986$ Internet Users in the EU on $2012 \mathrm{Q} 2$ Copyright @2012, Miniwatts Marketing Group

As it can be seen from presented tables and figures, the volume of Internet usage on the global and European level is pretty high. If we take a look at results of conducted research, the following conclusions can be made:

1) First, total number of Internet users is $34.3 \%$ on the global

2) Second, total number of Internet users is $63.2 \%$ on the European level

3) Third, total number of Internet users in the European Union (27 Member States) is $73 \%$

4) Fourth, total number of Internet users at the national level - a candidate for joining the European Union ( 9 countries - candidates) is $48.1 \%$

5) Fifth, percentage ratio of Internet users in Europe is $21.6 \%$ and in the world is and the world is $78.4 \%$

6) Sixth, percentage ratio of Internet users in the European Union's 15,3\% and in the world is $84.7 \%$.

\section{Case study analysis ${ }^{30}$}

DI (42) from Krusevac was found guilty. Appelated D.I. in period from February 2006. to January 2009. had unauthorized copied and put on market various authors' works, movies to DVD and Divx format, television shows, musical interpretations of various authors and musicians, recorded music concerts, computer programs and games in order to obtain self gain in the amount of RSD 70, 000.00. D.I. had previously purchased a copy and recorded them on

29 Internet users in EU for 2012. year; Internet World Stats, Copyright (C) 2012, Miniwatts Marketing Group; http://www.internetworldstats.com/stats.htm (05.04.2013.)

30 The practice of the Special Prosecutor's Office for the High-Tech Crime Department and the fight against cyber crime High Court in Belgrade, Serbia 
the memory of his computer as well as to optical discs (CD-R and DVD-R). Sale of those copies was advertised through his web site at www.dvdfilmovi.org. In order of establishing communication with clients and realization of purchase and sale, he had set electronic addresses dvdfilmovi22@gmail.com, dvdfilmovi22@hotmail.com dvdfilmovi22@yahoo.com. Also he had made catalog and price list contained of 7500 titles of copyright works and offered for sale. After offers arrive, he made copies on his computer of copyright work, than packed them and sorted them by order and they were sent by mail-cash on delivery. He achieved a gain of 70000.00 dinars, before the intervention of authorized officials of the Department for the Fight against cyber crime, SBPOK, the CID. Interior Ministry of Republic of Serbia on day 21.01.2009. raided the apartment and other premises in Krusevac street Topličkih Partizan No.22 and found and with confirmation of the suspect temporarily seized objects of the offense: a computer without black mark, nine hard drives "Western Digital” which contented 1450 of individual copyright works in DVD format and an unspecified number of installations of software and games, CD covers, etc..., and a total of 5914 pieces of prerecorded optical discs (5199 DVD and $715 \mathrm{CD}$ ), with contents of the mind above listed different types of copyright works, which were placed in envelopes handwritten by serial numbers from the catalog that was published on the Internet on page www.dvdfilmovi.org.

The Court's in his judgment, according to legal provisions 457 Paragraphl of the Code Criminal Procedure Paragraph and Pararaph 91. And 92 of Criminal Code D.I. imposed D.I. the confiscation of property gain in the amount of 70000.00 RSD, according to which D.I. is obligated to pay total amount of proceeds obtained by the designated time of the offense earned as a recipient of payments through postal money orders by mail traffic RJ „Krusevac” PTT „Serbia”.

KT FTC 33/2008 ${ }^{31}$ - Criminal offenses unauthorized access to a protected computer, computer network and electronic data processing from Article 302 paragraph 2. Related to Paragraph 1. of Criminal Code and the Computer Fraud Article 301. Paragraph 1. of Criminal Code.

The proposal to undertake certain investigative activities of the Special Prosecutor Kt.vtk. no. 33/2008 in 24 July 2009, M. Ž. (18) from Belgrade, was charged of unauthorized access to server NS1.ACCELERATEBIZ.COM in February 2008 through Internet. Server was physically located in Miami, Florida, USA, where, among others, was alo hosted a commercial Web site (Web site) which was intended for the education of future barista - expert for making coffee beverages, located at www.baristabasics.com.au. Violating measures of protection and using the code and the site administrator authority, on the Web site used

$31 \quad$ Special prosecution of cyber crime, „KT VTK 33/2008“: http://www.beograd.vtk.jt.rs/ index.php? view $=$ article \&catid $=50 \% 3 \mathrm{Abeybednost-racunarskih}$-podataka\&id $=118 \% 3 \mathrm{Akt}-$ vrk-33-2008\&tmpl=component $\&$ print $=1 \&$ layout $=$ default $\&$ page $=\& o p t i o n=$ com $_{-}$ content\&Itemid=89\&lang=sr (19.02.2011.) 
for business purchases (online store), M.Ž. had made unauthorized access to all payments and payment card data from the users of the above-mentioned Internet - store. He had unauthorized recorded - taken data from about 600 numbers, "American Express" and „VISA payment cards" born. Then, by using proceeded credit cards numbers (BIN numbers and CVV2) on 06.02.2008. years, on the Internet domain (www.e-ducan.com) he had tried to order and pay electronically two computer monitors with data from „American Express" and"' VISA payment cards, with last numbers: 3002, 0684, 1006, 1933, 3004 i 1011 on six occasions, using ID number 67999 for the registration and ordering online services „e-shop” and the IP address ..... 89,216. This IP address has been assigned to him by the Internet service provider „SBB Serbian Cable Network”. In order to gain illegal profit, he brought false information or he failed to enter the correct information regarding to owner of the card and billing address (billing address - an address that is linked to the parent bank card holder) which entered their personal data (name and surname, address) - that affected on result of electronic processing and transmission of data. He had achieved to order and pay for the monitor brand "Samsung SyncMaster 920NW", value \$285.50, with „Amex"s credit card last payment card numbers ${ }^{\star * *} 1011$ (BIN numbers) causing a damage to E-store in the amount of value monitore, which he had to reimburse on the bank account of actual cardholder.

KT FTC 55/2007 $7^{32}$ - A criminal offense of fraud under Article 208 Paragraph 1. in conjunction with Article 33rd and Article 61of Criminal Code.

Indictment by the Special Prosecutor KT VTK. Number 55/07, the judgment of the District Court in Belgrade found guilty J.S. (30) and his girlfriend T.D. (29) for fraud committed over the Internet. J.Š. and T.D. from Novi Sad in order to obtain an unlawful material benefit had falsely represented themselves as representatives of the Agency of "Exit apartments" in the period of January to 15th July 2007. Reffered agency provided accommodation for visitors of international music festival "Exit 07", with a place in Novi Sad, maintenance, lasting 12.-16. July 2007. Using a computer, computer networks and computer data, as well as other agencies material and products in electronic form, they had mislead British citizens, a total of 29 and thus led them to pay to the account, „Erste Bank „total 3937 euros or in RSD 314,960.00 din for agreed accommodation services. Defendant J.Š. had previously concluded contract on opening foreign currency current account with Erste Bank. He had also submitted an application for registration of international domain www.exitapartments.com with an Internet service provider "Neobee.net”. His acquaintance through the services of web hosting Internet - Provider „Eunet”, produced and posted website created by step instructions principal defendant. Website was usedfor offering living accom-

32 Special prosecution of cyber crime, „KT VTK 55/2007“: http://www.beograd. vtk.jt.rs/index.php?option $=$ com_content $\&$ view $=$ article $\&$ id $=62 \% 3 \mathrm{Akt}-\mathrm{vtk}$-br$5507 \&$ catid $=50 \% 3$ Abeybednost-racunarskih-podataka \&Itemid=89\&lang=sr (19.02.2011.) 
modation for the price of 30 to 60 euros in one-and three-room hotel „Gymnas” in Novi Sad. Defendants never had a business relationship and cooperation with mentioned hotel. According to the instructions on the website www.exitapartments.com, visitors had opportunity for bookingand aying in advance by laying a deposit of $30 \%$ of the package price to the specified account „Erste Bank”, through SWIFT, as one of the fastest ways of conducting international payments. Before taking deposits and arrival at „Exit 07” British and Irish citizens wre performing communication bycalling T.D. mobile number +381964 / 668th ... whichwas published on the site and through the designated electronic address info@exitapartments.com and exitapartments@neobee.net. During those phone calls she had falsely represented herself as manager of public relations agency „Exitapartments” from Novi Sad, answering their questions about payments, quality apartments, apartments position in relation to the place of the festival, and the like. After the payments had been done, she informed them about meeting place in Novi Sad, from where they would be transferred to heir apartments - which would be followed by the payment of the full amount. In addition to the reached agreements they avoided any contact with the victim after they arrival in Novi Sad.As it is described above, they have retaine the proceeds of 3937 euros in total or in RSD 314,960.00 dinars. Several British, except deposit, after getting in Novi Sad, gave them a cash in the amount of 710 euros. They had previously agreed meeting that on 10 07th 2007th in the cafe in the "Oliva" in Boulevard of Libertation No.133. in Novi Sad. The British gave them the money on behalf of the alleged co-payment for accommodation and she stamped them contract and a business card with the words „Agency for rent apartments." Taxi would take them to the hotel „Passenger” in Novi Sad, where they would have realized that they were cheated.

\section{Conclusion}

Seizing the characteristic features of cyberspace, but also taking into account other characteristics, such as high rates of potential and great opportunities, misuse of information technology, especially computer networks grows into a serious national and supranational - a global problem.

It is kind of crime that rapidly changes forms and forms of manifestation, the border between the states and the other injured. These criminal acts are carried out covertly, often without any visible and close spatial relationship even the offender and the victim. They are difficult to detect and even harder to prove. Those crimes remain virtually undetected for a long time until victim does not suffer huge damage that is visible in the computer information system.

It should be emphasized that beside criminal acts directed against the security of computer technology and information system elements, there are a num- 
ber of traditional criminal offenses with the usage of computers and computer components perform faster, easier, offenders are difficult to trace and the consequences are far more serious and more. ${ }^{33}$

We emphasize the problem of Internet abuse, given that this segment of the information technology has fundamentally revolutionized many areas of human life and work, by opening unexpected and so far the theory unprecedented possibilities of human communication and exchange of information in different fields of human creativity.

\section{Literature}

- $\quad$ Are you being stalked? - Cyberstalking, Privacy Rights Clearinghouse (PRC), San Diego, California, posted-june '94, revised-july '10; http:// www.privacyrights.org/fs/fs14-stk.htm\#1 (01.02.2011.)

- Babovic, M. (2004): „The hacker subculture and computer crime“, Legal Life, No. 9, year LIII, Book 485, 1-1356, Lawyers Association in Serbia, Belgrade

- $\quad$ Benedikt, M. (1991): Ed. Cyberspace First Steps. Cambridge, MA, MIT Press

- Drakulic, M. i Drakulic, R: „Cyber crime“, http://www.bos.rs/cepit/idrustvo/ sk/cyberkriminal.pdf (03.09.2010.)

- Gibson, W. (1984): Neuromancer, An Ace Book, The Ace Publishing Group, New York, Electronic edition: August 2003

- Internet World Stats, Copyright (C) 2012, Miniwatts Marketing Group; http://www.internetworldstats.com/stats.htm (05.04.2013.)

- Kesetovic, Z. (2008): „Internet as a tool of terrorists“, Journal of Safety, The Center for Security Studies, Year II, No. 4, Belgrade

- $\quad$ Kraut, R. Patterson, M., Lundmark, V., Kiesler, S., Mukopadhyay, T. \& Scherlis, W. (1998): „Internet paradox: A Social Technology That Reduces Social Involvement and Psychological Well-Being?” American Psychologist, 53, No.9, 1017-1031

- Kraut, R. Kiesler, S., Boneva, B., Cummings, J., Helgeson, V. \& Crawford, A. (2002): "Internet Paradox Revisited", Journal of social science, 58 , No. 1, 49-74

- Komlen-Nikolic, L.; Gvozdenovic, R.; Radulovic, S.; Milosavljevic, A.; Jekovic, R.; Zivkovic, V.; Zivanovic, S.; Reljanovic, M.; Aleksic, I. (2010):

33 Matijasevic, J. i Petkovic, M.: „Criminal offenses against the security of computer data analysis of positive solutions and significance in the context of combating cyber crime", Proceedings of the international scientific and professional conferences Criminal-forensic research, held on 14.-15. october 2011. year, International Association of Criminologists IAK, Banja Luka, 598-609,Vol. 4, 1/2011, 599 
Combating cyber crime, The Association of Public Prosecutors and Deputy Public Prosecutors of Serbia, Belgrade

- Matijasevic, J.; Spalevic, Z. (2010): „Specific characteristics of computer criminal offenses with regard to the law regulations", XLV International Scientific Conference on Information, Communication and Energy Systems and Technologies - ICEST 2010 CONFERENCE, 23.-26. June 2010., Faculty of Technical Sciences, University „St. Clement Ohridski“, Bitola, Ohrid, Macedonia, Proceedings, http://www.icestconf.org/index. php?option=com_content\&view=frontpage\&Itemid=98, 05.02.2011.

- Matijasevic, J. i Petkovic, M. (2011): „Criminal offenses against the security of computer data - analysis of positive solutions and significance in the context of combating cyber crime", Proceedings of the International scientific-technical conference Criminal Forensic Studies, held from 14.-15. october 2011., International Association of Criminologists - IAK, Banja Luka, 598-609,Vol. 4, No 1

- Mannes, A. (2007): „Threats to Internet“, Computer Crime Research Center, http://www.crime-research.org/articles/threat-ti-internet (06.02.2011.)

- Nie, N., Erbring, L. (2002): Internet and Mass Media: A Preliminary report, IT\&SOCIETY, 1, No.2, 134-14

- Education system "Ruder Boskovic" (2003): Abuse of the Internet - predators on children, Belgrade

- Petrovic, S.: „O about the information revolution in the context of abuse of information technology"; http://www.itvestak.org.rs/ziteh_04/radovi/ziteh20.pdf (20.09.2010.)

- Special Prosecutor’s Office for cyber crime, „KT VTK 09/2009“: http://www. beograd.vtk.jt.rs/index.php?option=com_content\&view=article\&id=116\%3Akt-vtk09-2009\&catid=49\%3Aintelektualna-svojina\&Itemid=88\&lang=sr (19.02.2011.)

- Special prosecution of cyber crime, „KT VTK 33/2008“: http://www. beograd.vtk.jt.rs/index.php?view=article\&catid=50\%3Abeybednost-racunarskihpodataka\&id=118\%3Akt-vrk-33-2008\&tmpl=component $\&$ print $=1 \&$ layout $=$ default $\&$ page $=\&$ option $=$ com_content $\&$ Itemid $=89 \&$ lang $=s r(19.02 .2011$. $)$

- Special prosecution of cyber crime, „KT VTK 55/2007“: http://www. beograd.vtk.jt.rs/index.php?option $=$ com_content $\& v i e w=$ article $\&$ id $=62 \% 3 \mathrm{Akt}$-vtkbr-5507\&catid $=50 \% 3$ Abeybed nost-racunarskih-podataka\&Itemid $=89 \&$ lang $=$ sr (19.02.2011.)

- Privacy Rights Clearinghouse (PRC), a nonprofit consumer organization, San Diego, California, http://www.privacyrights.org/about_us.htm (01.02.2011.)

- Prlja, D.; Reljanović, M. (2009): „Cybercrime - a comparative experience“, Foreign legal life, No. 3, Institute of Comparative Law, Belgrade

- Radicati Group Statistics, http://email.about.com/od/emailtrivia/f/emails_per_ day.htm (12.02.2011.) 
- $\quad$ Schneider, V, Hyner, D. (2003): “The Global Governance of Cybercrime: Issue Space and the Transnational Policy Network, University of Konstanz, (28.08.2010.) http://www.essex.ac.uk/ecpr/events/jointsessions/paperarchive/edinburgh/ws11/SchneiderHyner.pdf

- The Attorney General Report, Cyberstalking: A New Challenge for Law Enforcement and Industry, http://www. usdoj.gov/criminal/cybercrime (25.08.2010.)

- Uljanov, S., Urosevic, V., Ivanovic, Z. (2010): „Hightech crime from the perspective of the international criminal police cooperation ", Proceedings of the international scientific conference International and national cooperation and coordination in the fight against crime, Vol. 3, No. 1, 530-541, International Association of Criminologists, Banja Luka

- United Nations office at Vienna, Global studies on organized crime (1999): http://www.oun.org (03.09.2010.)

Paper received: December $4^{\text {th }}, 2013$

Rad primljen: 4. decembar 2013.

Approved for publication: February $28^{\text {th }}, 2014$ Odobren za štampu: 28. februar 2014. 
The significance and modalities of internet abuse as the primary global... 297

Doc. dr Jelena Matijašević Obradović

Pravni fakultet za privredu i pravosuđe u Novom Sadu

Univerzitet Privredna akademija u Novom Sadu

\section{ZNAČAJ I MODALITETI ZLOUPOTREBE INTERNETA KAO OSNOVNE GLOBALNE KOMUNIKACIJSKE RAČUNARSKE MREŽE U SAJBER PROSTORU}

\section{S a ž e t a k}

Uporedo sa brzim razvojem računara razvile su se i računarske mreže. Kompjuterska krivična dela se vrše u specifičnom okruženju - sajber prostoru, čija je važna karakteristika transnacionalni obim, koji prevazilazi teritorijalnu kontrolu nacionalnih država. Nesumnjivo je da računarske mreže mogu biti predmet različitih zloupotreba. $U$ tom smislu, pojavljuju se u trostrukoj ulozi: kao cilj ili objekat napada, kao sredstvo ili alat, ili kao okruženje izvršenja krivičnog dela. U pitanju je takva vrsta kriminaliteta, koji brzo menja forme i oblike ispoljavanja, granice među državama, kao i vrstu oštećenog. Posebno izražen problem u ovoj oblasti jeste zloupotreba interneta, kao osnovne globalne komunikacijske kompjuterske mreže, budući da je ona iz temelja revolucionisala mnoge oblasti ljudskog života i rada. Iz tih razloga predmet rada jeste analiza najznačajnijih modaliteta zloupotrebe interneta, kao i obima korišćenja i značaja interneta za savremeno društvo. Poseban odeljak rada posvećen je analizi slučajeva iz prakse pravosudnih organa Republike Srbije.

Ključne reči: sajber prostor, računarske mreže, internet, studija slučaja 